\title{
Effects of Blind Channel Equalization using the Regressive Accelerator Algorithm Version $\gamma$
}

Johanna Andrea Hurtado Sánchez / johannahurtado@unicauca.edu.co

Pablo Emilio Jojoa Gómez / pjojoa@unicauca.edu.co

Universidad del Cauca, Popayán-Colombia

ABSTRACT We present a blind channel equalization scheme, applied to $\gamma$ version regressive acceleration algorithm, which uses self-taught equalization techniques to study the characteristics of both, the second and the higher order moments for the transmitted signal, used to calculate the signal of error and thus, to make an optimal estimation of the transmitted symbols. This way, simulations of the obtained results are done in comparison with the algorithms based on the stochastic gradient and with the Bussgang algorithms. The results of that simulations show how, using the regressive acceleration algorithm version $\gamma$, a better detection of transmitted bits and higher convergence speeds are obtained, with a minimum mean square error.

KEYWORDS Blind equalization; adaptive algorithms; convergence speed; data estimation.

Efectos de la ecualización ciega de canal utilizando el algoritmo acelerador regresivo versión $\gamma$

RESUMEN Se presenta un esquema de ecualización ciega de canal, donde se aplica el algoritmo acelerador regresivo versión $\gamma$, el cual utiliza las técnicas de ecualización autodidacta que estudian las características de los momentos de segundo orden y de orden superior de la señal transmitida, usados para calcular la señal de error, con el fin de realizar una óptima estimación de los símbolos transmitidos. Con ello se simulan los resultados obtenidos en comparación con los algoritmos basados en el gradiente estocástico y en los algoritmos de Bussgang. Los resultados de las simulaciones muestran que, utilizando el algoritmo acelerador regresivo versión $\gamma$, se obtiene una mejor detección de los bits trasmitidos y mayores velocidades de convergencia, con un error cuadrático medio mínimo.

PALABRAS CLAVE Ecualización ciega; algoritmos adaptativos; velocidad de convergencia; estimación de datos.
Efeitos da equalização cega de canal usando o algoritmo acelerador regressivo versão $\gamma$

RESUMO É apresentado um esquema de equalização cega de canal, onde é aplicado o algoritmo de aceleração regressiva versão $\gamma$, que utiliza técnicas de equalização autodidatas que estudam as características dos momentos de segunda ordem e de ordem superior do sinal transmitido, utilizados para calcular o sinal de erro, a fim de fazer uma estimativa ótima dos símbolos transmitidos. Com isso são simulados os resultados obtidos em comparação com os algoritmos baseados no gradiente estocástico e nos algoritmos de Bussgang. Os resultados das simulações mostram que, usando o algoritmo de aceleração regressiva versão $\gamma$, obtém-se uma melhor detecção dos bits transmitidos e maiores velocidades de convergência, com um erro quadrático médio mínimo,

PALAVRAS-CHAVE Equalização cega; algoritmos adaptativos; velocidade de convergência; estimação de dados. 


\section{Introduction}

A blind channel equalizer is a scheme inspired in an adaptive algorithm trying to detect the transmitted data sequence which has been distorted through its travel within the communications channel. The algorithms of the blind equalizer have been widely used in fields such as signal processing, image reconnaissance, design of control systems, and objects location in the natural space, among others.

The implementation of adaptive equalizers allowing the compensation of the channel interference caused by the Inter-Symbol Interference [ISI] and noise dates to the 1960s decade. The pioneer works by Widrow-Holf (1960),Lucky (1966), Saltzberg (1968),and Lugannani (1969) are a good example of researchers who contributed to the algorithms conception, being improved nowadays. This has improved the performance in the signal reception presenting distortions (Aquino, 2012). These algorithms are divided in two large groups: the ones using a training signal — so-called supervised-; and blind or self-taught algorithms called unsupervised. The first ones, mentioned in the works presented by Jojoa (2003), Aquino (2012), Erdogmus \& Principe (2002), and Rocha (2005) use a training sequence available in the receiver. Consequently, they can calculate the error signal as the difference between the training signal and the signal outside the equalizer; allowing the periodic adjustment of the equalizer coefficients.

The main training adaptive algorithms are the Least Mean Square [LMS], Least Square [LS], and Recursive Least Square [RLS]. The LMS algorithm is important due to its low computational cost, although it offers a relatively slow convergence speed (Madeira, 2005). Regardless of the fact that this supervised equalization method presents good results relative to detection and convergence speed, it is not very employed because the use of training sequences reduces the channel capacity; hence, the idea of working with self-taught algorithms arose. These last ones have been proposed by Madeira (2013); Rolim (2005); Shalvi \& Weinstein (1990); Neves, Attux, Suyama, Miranda, \& Romano (2006). These algorithms do not use training sequences, only the statistical knowledge of the transmitted signal (Benveniste, Goursat, \& Ruget, 1980).

Some of the self-taught algorithms are the Constant-Modulus Algorithm [CMA] (Romano, Attux, Cavalcante, \& Suyama, 2016), the Lucky direct choice algorithm (1966), Sato's algorithm (1975), and the Multi-Mode Algorithm [MMA]. The most employed nowadays is the CMA; it is computationally more complex and it is considered as a self-taught version of the LMS algorithm due to their similarities. Furthermore, it handles an adaptation weight that defines the convergence speed and the robustness degree:

\section{Introducción}

Un ecualizador ciego de canal es un esquema inspirado en un algoritmo adaptativo que intenta detectar la secuencia de datos transmitida que ha sido distorsionada a lo largo del canal de comunicación. Los algoritmos del ecualizador ciego han sido ampliamente utilizados en campos como procesamiento de señales, reconocimiento de imágenes, diseño de sistemas de control y visión de objetos situados en el espacio natural, entre otros.

La implementación de ecualizadores adaptativos, que permiten compensar la interferencia del canal producida por la ISI y el ruido, se remontan a la década de 1960, con los trabajos pioneros de Widrow-Holf (1960), Lucky (1966), Saltzberg (1968) y Lugannani (1969), quienes contribuyeron a la creación de algoritmos que han sido mejorados hasta el día de hoy, lo que ha permitido lograr un mejor desempeño en la recepción de las señales que presentan distorsiones (Aquino, 2012). Estos algoritmos se dividen en dos grandes grupos: algoritmos que utilizan una señal de entrenamiento, denominados supervisados; y algoritmos ciegos o autodidactas, denominados no supervisados. Los primeros, mencionados en los trabajos de Jojoa (2003), Aquino (2012),Erdogmus y Principe (2002) y Rocha (2005), utilizan una secuencia de entrenamiento que está disponible en el receptor. De esa manera, pueden calcular la señal de error como la diferencia entre la señal de entrenamiento y la señal a la salida del ecualizador, para así ajustar periódicamente los coeficientes del ecualizador.

Los principales algoritmos adaptativos de entrenamiento son LMS [Least Mean Square], LS [Least Square] y RLS [Recursive Least Square]. Se destaca el algoritmo LMS debido a su bajo costo computacional, aunque ofrece una velocidad de convergencia relativamente lenta (Madeira, 2005). A pesar de que este método de ecualización supervisado presenta buenos resultados de detección y velocidad de convergencia, no es muy utilizado debido a que el uso de secuencias de entrenamiento disminuye la capacidad del canal, de ahí la idea de trabajar con algoritmos autodidactas, los cuales son propuestos por: Madeira (2013); Rolim (2005); Shalvi y Weinstein (1990); Neves, Attux, Suyama, Miranda, y Romano (2006). Estos algoritmos no utilizan secuencias de entrenamiento, solo usan el conocimiento estadístico de la señal transmitida (Benveniste, Goursat, \& Ruget, 1980).

Entre los algoritmos autodidactas se encuentran: el Constant-Modulus Algorithm [CMA] (Romano, Attux, Cavalcante, \&Suyama, 2011), el algoritmo de decisión directa de Lucky (1966), el algoritmo de Sato (1975) y el algoritmo multimodo [Multi-Mode Algorithm, MMA]. El más utilizado es el algoritmo CMA, es computacionalmente más complejo y se considera como una versión autodidacta del algoritmo LMS, debido a su similitud. También maneja un paso de adaptación que define la velocidad de convergencia y el grado de robustez: a mayor valor del paso de adaptación, mayor velocidad de convergencia y menor robustez(Madeira, 2013).

Este artículo de investigación implementa un esquema de ecualización ciega de canal utilizando el algoritmo $\mathrm{AR} \gamma$ con 
el uso de estadísticas de orden superior de los algoritmos de Bussgang y la evaluación del error cuadrático medio en la detección de símbolos. Está dividido en tres sesiones: en la primera se muestran los métodos de ecualización ciega de canal con los algoritmos de Bussgang; en la siguiente se implementa un ecualizador ciego, utilizando el algoritmo AR $\gamma$ con las estadísticas de orden superior de los algoritmos de Bussgang; y en la última se muestran los resultados de la implementación y las conclusiones.

\section{Materiales y método}

En los sistemas de comunicación digital es necesario recuperar la señal transmitida que ha sido deteriorada por los efectos nocivos del canal de comunicaciones, por tal motivo es necesario incluir en el receptor un ecualizador adaptativo capaz de mitigar dichos efectos. El modelo general de un sistema de comunicación de tiempo discreto está dado en función de una secuencia de símbolos transmitida a través de una canal de comunicaciones, el cual introduce interferencias que generan en la recepción una versión distorsionada de la secuencia de datos transmitida. La Figura 1 muestra el diagrama de bloques general de un sistema de comunicación en tiempo discreto que utiliza ecualización no supervisada.

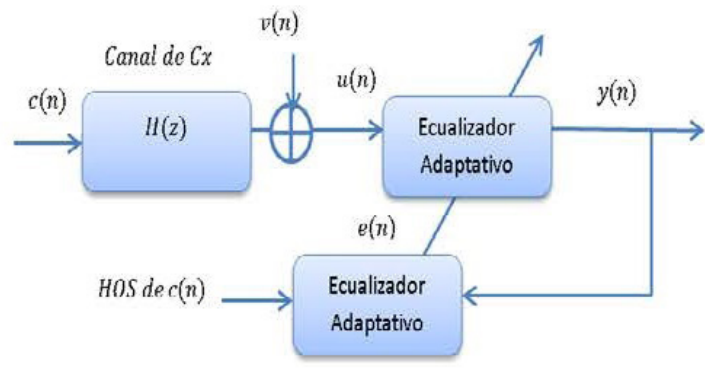

Figure 1. Unsupervised equalization basic scheme Esquema básico de ecualización no supervisada

El sistema de comunicación que utiliza un ecualizador está conformado por una secuencia de datos de entrada denominada $c(n)$, la cual es no gaussiana, independiente e idénticamente distribuida (i.i.d); el canal que incluye el sistema de transmisión y modulación y recepción/demodulación se representa a través de $H(z), v(n)$ ruido AWGN (aditivo blanco y gaussiano), $u(n)$ señal con ruido a la salida del canal, $e(n)$ señal de error y y $(n)$ señal a la salida del ecualizador. Para este tipo de modelos es apropiado representar las distorsiones causadas por el canal a través de un modelo lineal descrito por una respuesta al impulso unitario finita. La función de transferencia se presenta en la ecuación (1).

$$
H(z, n)=\sum_{k=0}^{N-1} h_{k, n} Z^{-k}
$$

en donde:

$\mathcal{N}$ es la longitud de la respuesta unitaria del canal; y

$h_{(k, n)}$ los coeficientes en el instante de tiempo $n$.

Para este tipo de modelos se debe tener en cuenta los siguientes aspectos a la hora de implementar la ecualización de the higher the adaptation weight, the higher the convergence speed and lower robustness (Madeira, 2013).

This research article implements a blind channel equalization scheme using the AR $\gamma$ algorithm by employing higher order statistics from the Bussgang algorithm and the root mean error evaluation in the symbol detection. It is divided in three sections: the first one shows the blind channel equalization methods with the Bussgang algorithms, the following section shows the implementation of a blind equalizer by using the AR $\gamma$ algorithm with the higher-level statistics of the Bussgang algorithms; and the last section presents the implementation results and the conclusions.

\section{Materials and Method}

Within the digital communication systems, it is necessary to recover the transmitted signal, which has been affected by the harmful effects by the communications channel. For this reason, it is necessary to include in the receiver an adaptive equalizer capable to mitigate these effects. The general model of a discrete time communication system is based on a sequence of symbols transmitted through a communications channel; this last introduces interferences, generating in the receiver a distorted vision of the transmitted data sequence. Figure 1 shows the general block diagram of a discrete time communication system using non-supervised equalizing.

The communication system using an equalizer is formed by an input data sequence named $c(n)$, which is not gaussian, independent, and identically distributed; the channel including the transmission/modulation and reception/demodulation systems is represented though $H(z), v(n)$ represents the AWGN noise (additive, white, and gaussian), $u(n)$ is a signal with noise at the exit of the channel, $e(n)$ is the error signal, and $y(n)$ is the signal at the exit of the equalizer. For this type of models, it is appropriate to represent the distortions caused by the channel using a linear model described by the response to the finite unitary impulse. The transfer function is presented in (1).

$$
H(z, n)=\sum_{k=0}^{N-1} h_{k, n} Z^{-k}
$$

where:

$\mathcal{N}$ is the length of the unitary channel response; and

$h_{(k, n)}$ are the coefficients in the $n$ instant.

For these types of models, it is important to consider the following aspects when implementing the channel equalizing. First, the Inter-Symbol Interference [IS], which is a phenomenon occurring due to the channel dispersive effect; it is the result of the convolution between the transmitted signal and its response to the unitary impulse. In most of the wireless 
communications applications, this dispersive effect is observed in the signal as propagation delays caused by the reflection of the signal through several trajectories. This generates a detection of time desynchronized signals. The second aspect to consider is the intrinsic noise present in every communications channel, which affects the equalizer performance when the signal detection is performed. The last one is the channel model due to limitations detecting a signal transmitted via a non-linear channel (or no-minimal phase channel); these channels can be time-variant such as the fading channels.

When the implementation of the adaptive equalizer is performed, it is supposed that the supervised techniques are limited to the use of systemic resources, where working with training sequences to calculate the error signal and updating the equalizer coefficients is not optimal. This is mainly caused because of the bandwidth consumption and the reduction in the convergence speed. Consequently, we used the blind equalization method - or unsupervisedby using statistics of the transmitted signal to calculate the error signal and correct the channel dispersive effects. This equalization technique is characterized by using methods based on Second Order Statistics [SOS], Higher Order Statistics [HOS], and methods based in information theory.

\section{A. Blind Channel Equalization Methods}

\section{Methods Based on Second Order Statistics}

The methods based on second order statistics use the features of the so-called seasonality cycle in the $\mathrm{u}(\mathrm{n})$ signal to calculate the error signal in the communications channel. This kind of method does not present phase ambiguity, which allows to obtain better performance and detection of the transmitted symbols. Its main disadvantage relies on the exact estimation of the channel order and the data estimation without noise; therefore, it does not present an adequate performance in real situations. Some techniques using SOS include the linear prediction ones, based on subspaces, and least-squares (Romano et al., 2016).

\section{Methods Based on Statistics with Order Higher than Two}

The function of this method is to show that the random processes of the $y(n)$ and $c(n)$ signals (Figure $\mathbf{1})$ have the same features in their any-order moments, i.e., $\mathrm{E}\left\{|\mathrm{y}|^{\mathrm{k}}\right\}=\mathrm{E}\left\{|\mathrm{c}|^{\mathrm{k}}\right\}$ for all $\mathrm{k}>0$, where the equalizer can adjust its coefficients seeking that the moments of the $y(n)$ signal are the same than the ones in the $c(n)$ signal.

This kind of methods also uses the fourth order moments, known as curtoses. These ones allow a correct detection of the signal if $\mathrm{E}\left\{|\mathrm{y}|^{4}\right\}=\mathrm{E}\left\{|\mathrm{c}|^{4}\right\}$. A method using these superior order statistics is the constant module criteria where, in certain circumstances, is very similar to the Shalvi-Weinstein criteria. This method employs the moments canal. Primero, la Interferencia Intersimbólica [Inter-Symbol Interference, ISI, que es un fenómeno que ocurre debido al efecto dispersivo del canal y es el resultado de la convolución entre la señal transmitida y su respuesta al impulso unitario. En la mayoría de aplicaciones de comunicación inalámbrica se observa el efecto dispersivo de la señal debido a los diferentes atrasos de propagación, que ocasionan las reflexiones de la señal por diferentes trayectorias, lo que genera una detección de señales desfasadas en el tiempo. El segundo aspecto a considerar es el ruido intrínseco presente en todo el canal de comunicación, que afecta el desempeño del ecualizador al realizar la detección de la señal. El tercero es el modelo del canal, debido a las limitaciones al detectar una señal trasmitida por canales no lineales o de fase no mínima, que pueden ser variantes en el tiempo, como por ejemplo los canales con desvanecimiento.

En la implementación del ecualizador adaptativo es de suponer que las técnicas supervisadas están limitadas al uso de recursos sistémicos, en los cuales no es óptimo trabajar con secuencias de entrenamiento para calcular la señal de error y de esta manera actualizar los coeficientes de ecualizador, debido al consumo de ancho de banda y a la disminución en la velocidad de convergencia. Por ello, se recurre al método de ecualización ciega o no supervisada, el cual hace uso de estadísticas de la señal transmitida para calcular la señal de error, para de esta forma corregir los efectos dispersivos del canal. Esta técnica de ecualización se caracteriza por la utilización de métodos basados en estadísticas de segundo orden [Second Order Statics, SOS], métodos de orden superior a dos [Higher Order Statistics, HOS] y métodos basados en la teoría de la información.

A. Métodos de ecualización ciega de canal

\section{Métodos basados en estadísticas de segundo orden}

Los métodos basados en estadísticas de segundo orden utilizan las características de ciclo estacionalidad de la señal u(n) para calcular la señal de error en el canal de comunicación. Este tipo de métodos no presenta ambigüedad de fase, lo que le permite obtener un mejor rendimiento y la detección de los símbolos transmitidos. Su desventaja principal radica en la estimación exacta del orden del canal y la estimación de los datos en ausencia de ruido, por lo que no presenta un buen desempeño en condiciones reales. Algunas técnicas que utilizan estadísticas de segundo orden incluyen: las de predicción lineal, las basadas en subespacios y las de mínimos cuadrados (Romano et al., 2011).

Métodos basados en estadísticas de orden superior a dos La función de este método es mostrar que los procesos aleatorios de las señales $y(n)$ y $c(n)$ (FIGURA 1), poseen las mismas características en sus momentos de cualquier orden, es decir, $\mathrm{E}\left\{|\mathrm{y}|^{\mathrm{k}}\right\}=\mathrm{E}\left\{|\mathrm{c}|^{\mathrm{k}}\right\}$ para todo $\mathrm{k}>0$, en donde el ecualizador puede ajustar sus coeficientes de tal forma que los momentos de la señal $y(n)$ sean iguales a los momentos de la señal $c(n)$.

Este tipo de método también hace uso de los momentos de orden cuatro, conocidos como curtoses, los cuales permiten detectar correctamente la señal si $\mathrm{E}\left\{|\mathrm{y}|^{4}\right\}=\mathrm{E}\left\{|\mathrm{c}|^{4}\right\}$. Un método que utiliza estadísticas de orden superior es el criterio de módulo constante que sobre ciertas circunstancias es muy similar 
al criterio de Shalvi-Weinstein. Este método usa los momentos de orden dos y cuatro de la señal transmitida para detectar la señal de forma confiable a la salida (Madeira, 2005).

\section{Métodos basados en la teoría de la información}

Los métodos basados en la teoría de la información utilizan la función de densidad de probabilidad, de tal forma que la ecualización de la señal es óptima siempre y cuando la (f.d.p) de la señal $y(n)$ sea igual a la (f.d.p) de $c(n)$, lo que permite minimizar la entropía del error entre esas dos secuencias aleatorias (Erdogmus \& Principe, 2002; Lathi, 1998).

Un tipo de métodos que utiliza la teoría de la información para estimar sus parámetros es el de máxima verosimilitud ML [Maximum Likelihood], este tipo de métodos también utiliza la función de densidad de probabilidad de las dos señales y(n) y c(n). Sin embargo, una buena estimación de la función de ML exige mayores recursos computacionales, por lo que los procesos de simulación tienden a ser más complejos.

\section{B. Algoritmos de Bussgang de ecualización ciega de canal}

Los algoritmos de Bussgang hacen uso de estadísticas de orden superior sobre la señal transmitida y utilizan una ecuación de actualización de los coeficientes dada por la ecuación (2).

$$
w(n+1)=w(n)+\mu\{\psi[y(n)]-y(n)\} x(n),
$$

en donde:

$w(n)$ es el vector de parámetros en el instante $\mathrm{n}$,

$x(n)$ is el vector de entrada del ecualizador,

$\mu$ es el tamaño del paso, y

$\psi[y(n)]$ corresponde al estimador no lineal sin memoria de la señal transmitida $c(n)$.

Este estimador (ver TABLA 1) utiliza estadísticas de orden superior de $x(n)$ para obtener una aproximación al símbolo transmitido. Dentro de los algoritmos de Bussgang que utilizan estadísticas de orden superior se encuentran: el algoritmo de decisión directa DDA, el algoritmo de Sato y el algoritmo de módulo constante.

\section{Algoritmo ARy basado en el gradiente estocástico}

El algoritmo acelerador regresivo versión $\gamma$ surge a partir del algoritmo acelerador de tiempo continuo propuesto en 1998 por F. Pait (Jojoa, 2003), el cual, al ser discretizado genera tres versiones conocidas como Algoritmo Acelerador Completo [AAC], Algoritmo Acelerador Progresivo [APCM] y Algoritmo Acelerador Regresivo [ARCM] en donde los esfuerzos of order two and four of the transmitted signal to correctly detect the signal in the exit (Madeira, 2005).

\section{Methods Based on the Information Theory}

The methods based on the information theory use the Probability Density Function (PDF) seeking that the signal equalization is optimal, always that the PDF of the $y(n)$ signal is the same than the PDF of $\mathrm{c}(\mathrm{n})$. This allows to minimize the error entropy between these two random sequences (Erdogmus \& Principe, 2002; Lathi, 1998).

One kind of method using the information theory to estimate its parameters is the Maximum Likelihood [ML] one, it also uses the PDF of two signals, say y(n) andc(n).Nevertheless, a good estimation of the ML function demands higher computational resources, making more complex the simulation processes.

\section{B. Bussgang Channel Blind Equalization Algorithms}

The Bussgang algorithms use SOS over the transmitted signal and they also use an updated equation in the coefficients, given by (2).

$$
w(n+1)=w(n)+\mu\{\psi[y(n)]-y(n)\} x(n),
$$

where:

$w(n)$ is the parameters vector in the instant $n$,

$x(n)$ is the equalizer input vector,

$\mu$ is the step size, and

$\psi[y(n)]$ corresponds to the memory-less non-linear estimator of the transmitted signal $c(n)$.

This estimator (see TABLE 1) uses superior order statistics of $\mathrm{x}(\mathrm{n})$ to obtain an approximation to the transmitted symbol. Within the Bussgang algorithms using SOS, we can mention the Direct Decision Algorithm [DDA], the Sato algorithm, and the constant module algorithm.

\section{ARy Algorithm Based on the Stochastic Gradient}

The regressive Accelerator algorithm version $\gamma$ was born from the continuous time accelerator algorithm proposed in 1998 by Pait (Jojoa, 2003). When this algorithm is discretized, it generates three new versions known as complete accelerator algorithm [AAC], progressive accelerator

Table 1. Estimators and their corresponding cost functions / Estimadores y sus correspondientes funciones de costo

\begin{tabular}{lclll}
\hline Algorithm & Estimator $\psi(y(n))$ & Cost function & Higher order statistics & Coefficient updating equation \\
Algoritmo & Estimador $\psi(y(n))$ & Función de costo & Estadísticas de orden superior & Ecuación de actualización de coeficientes \\
\hline DDA & $\operatorname{dec}(y(n))$ & $J_{D D}=E\left[\left(y(n)-\operatorname{dec}(y(n))^{2}\right]\right.$ & - & $w(n+1)=w(n)+\mu\{\operatorname{dec}[y(n)]-y(n)\} x(n)$ \\
Sato & $\operatorname{sign}[y(n)]$ & $J_{S a t o}=E\left[\left(k_{1} \operatorname{sign}[y(n)]-|y(n)|\right)^{2}\right]$ & $k_{1}=E\left\{|a(n)|^{2}\right\} / E\{|a(n)|\}$ & $w(n+1)=w(n)+\mu\left\{k_{1} \operatorname{sign}[y(n)]-y(n)\right\} x(n)$ \\
CMA & $y(n)\left[k_{2}-|y(n)|^{2}\right]$ & $J_{C M}=E\left[\left(|y(n)|^{2}-k_{2}\right)^{2}\right]$ & $k_{2}=E\left\{|\alpha(n)|^{4}\right\} / E\left\{|\alpha(n)|^{2}\right\}$ & $w(n+1)=w(n)+\mu\left\{y(n)\left[k_{2}-|y(n)|^{2}\right]\right\} x(n)$ \\
\hline
\end{tabular}


algorithm [APCM], and regressive accelerator algorithm [ARCM], where the efforts were pointed out to reduce the computational complexity of ARCM. From here, the ArI arose. It has features such as having three adjustment parameters (Alpha, Gamma, and M1) and it is able to achieve a good convergence speed, entailing to the reduction of the final measurement error (Solarte, 2012). Equations (3), (4), (5), (6), and (7) represent theAR $\gamma$ algorithm.

$$
\begin{gathered}
e(n)=X^{T} w[n-1]-d(n) \\
g(n)=\frac{e(n)+\gamma X^{T}(n) q(n-1)}{1+\alpha \gamma X^{T}(n) M_{1} X(n)} \\
q(n)=\frac{r}{\alpha+\gamma} q(n-1)-\alpha g(n) m 1(n) \\
w(n)=w(n-1)+\alpha q(n) \\
d(n)=X^{T}(n) w_{0}(n)+r(n),
\end{gathered}
$$

where:

$x$ (n) represents the input signal vector;

$w(n)$ is the coefficients vector of the adaptive filter;

$d(n)$ the scalar, which is the desired signal in the instant $n$; $e(n)$ the scalar, which is the error signal in the instant $n$; $g(n)$ the auxiliary scalar in the instant $n$;

$q(n)$ the auxiliary vector;

$w_{0}$ the optimum coefficients vector; and

$\alpha, \gamma$ and $m 1$ are fixed adjustment parameters.

\section{Results}

The implementation of the blind equalizer using the $\mathrm{AR} \gamma$ algorithm was developed using statistics with order higher than 2 to perform the estimation of the transmitted data. We considered the linear estimators of the Bussgang algorithms to adapt the AR $\gamma$ to the blind equalization mode. This allowed us to execute the calculation of the Mean Squared Error [MSE]. Using this MSE value, we gathered the corresponding values to the variables $g(n), q(n)$ and $w(n)$ of the AR $\gamma$. The setup parameters of this algorithm are calculated by setting up a parameter and modifying the other two in a range between 0.1 and 6 ; by increasing the values in steps of 0.1 , a minimal squared error is obtained. The transmitted symbols constellation is 4-QAM, the channel

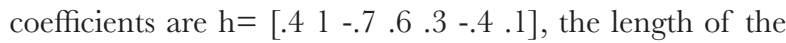
data is $\mathrm{L}=2000$, and the signal to noise relation is $25 \mathrm{~dB}$.

\section{A. Estimator of the Direct Decision Algorithm Adopted to the AR One}

Equations (8) to (12) represent the AR $\gamma$ algorithm with decision statistics. se enfocaron en disminuir la complejidad computacional de ARCM, con lo que surgió el algoritmo AR $\gamma$, que tiene como características: tener tres parámetros de ajuste (Alfa, Gama y M1) y lograr una buena velocidad de convergencia y, por tanto, la reducción del error de medida final (Solarte, 2012). Las ecuaciones (3), (4), (5), (6) y (7) representan al algoritmo AR $\gamma$.

$$
\begin{gathered}
e(n)=X^{T} w[n-1]-d(n) \\
g(n)=\frac{e(n)+\gamma X^{T}(n) q(n-1)}{1+\alpha \gamma X^{T}(n) M_{1} X(n)} \\
q(n)=\frac{\gamma}{\alpha+\gamma} q(n-1)-\alpha g(n) m 1(n) \\
w(n)=w(n-1)+\alpha q(n) \\
d(n)=X^{T}(n) w_{0}(n)+r(n),
\end{gathered}
$$

en donde:
$x(n)$ representa el vector de la señal de entrada;
$w(n)$ el vector de coeficientes del filtro adaptativo;
$d(n)$ el escalar que corresponde a la señal deseada en el instante $n$; $e(n)$ el escalar que corresponde a la señal de error en el instante $n$;
$g(n)$ el escalar auxiliar en el instante $n$;
$q(n)$ el vector auxiliar;
$w_{0}$ el vector de coeficientes óptimo; y
$\alpha, \gamma$ y $m 1$ son parámetros de ajuste fijo.

\section{Resultados}

La implementación del ecualizador ciego utilizando el algoritmo $\mathrm{AR} \gamma$ se desarrolla con el uso de estadísticas de orden superior a dos para realizar la estimación de los datos transmitidos. Se tienen en cuenta los estimadores lineales de los algoritmos de Bussgang, para adaptar el algoritmo AR $\gamma$ al modo de ecualización ciega, y así realizar el cálculo del error cuadrático medio [Mean Squared Error, MSE] y, con base en él, obtener los valores correspondientes a las variables $\mathrm{g}(\mathrm{n}), \mathrm{q}(\mathrm{n})$ y w(n) del $\mathrm{AR} \gamma$. Los parámetros de ajuste del algoritmo $\mathrm{AR} \gamma$ son calculados fijando un parámetro y variando los otros dos en un rango entre 0.1 y 6 , incrementando el valor en pasos de 0.1 , con el fin de obtener un error cuadrático mínimo. La constelación de símbolos transmitida es 4-QAM, que pasa por un canal lineal cuyos coeficientes son $\mathrm{h}=\left[\begin{array}{llll}.4 & 1 & -.7 & -7\end{array}\right.$ -.4 .1], la longitud de los datos es de $\mathrm{L}=2000$ y la relación señal a ruido es de $25 \mathrm{~dB}$.

A. Estimador del algoritmo de decisión directa adaptado al algoritmo ARy Las ecuaciones (8) a (12) representan al algoritmo AR $\gamma$ con estadísticas de decisión.

$$
\begin{gathered}
y(s)=x_{n}^{\prime} * w_{n} \\
e(n)=y(s)-\operatorname{sign}[y(s)] \\
g(n)=\frac{e(n)+\gamma X^{T}(n) q(n-1)}{1+\alpha \gamma X^{T}(n) m_{1} X(n)} \\
q(n)=\frac{\gamma}{\alpha+\gamma} q(n-1)-\alpha g(n) M_{1} X(n)
\end{gathered}
$$




$$
w(n)=w(n-1)+a q(n)
$$

La ecualización ciega de canal utilizando el AR $\gamma$ en modo de configuración de decisión directa se implementó fijando un valor para gama entre 0.01 hasta 1 , y variando los dos parámetros de ajuste Alfa y ml, en un intervalo de 0.01 hasta 6, en aumentos de 0.1. Con ello se obtuvo un error cuadrático mínimo de 0.022331 , con un valor de alfa en $0.41 \mathrm{y} \mathrm{ml}$ en 5.8. los resultados muestran que para dichos valores de alfa, gama y $\mathrm{ml}$ se obtiene una mejor estimación de los datos transmitidos y una reducción considerable del error cuadrático medio(ver TABLA 2 y Figuras 2 y 3 ).

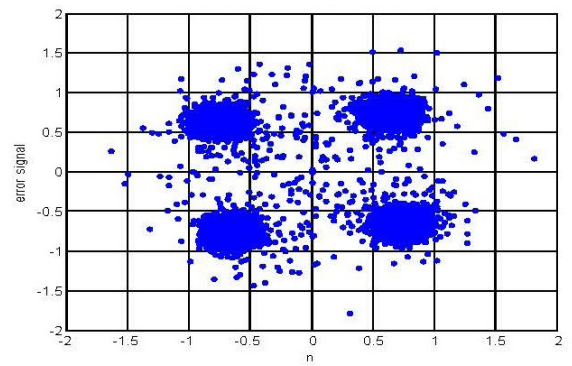

Figure 2. Equalization with decision statistics / Ecualización con estadísticas de decisión

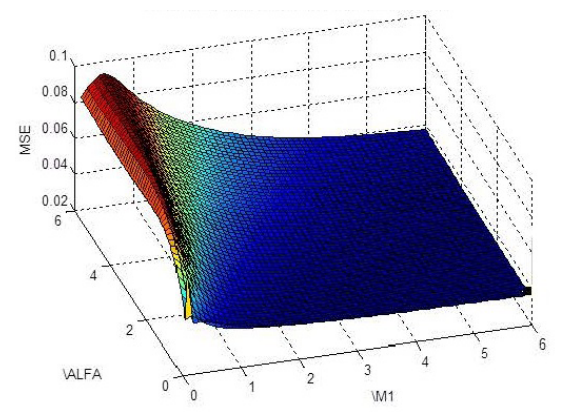

Figure 3. MSE with variations in gama and alfa / MSE con la variación de gama y alfa

B. Estimador del algoritmo de Sato adaptado al algoritmo ARy

Las ecuaciones (13) a (18) representan al algoritmo AR $\gamma$ con estadísticas de Sato.

$$
\begin{gathered}
y(s)=x_{n}^{\prime} * w_{n} \\
e(n)=y(s)-(k * \operatorname{sign}[y(s)]) \\
k=\frac{E\left[x^{2}(n)\right]}{E[|x(n)|]} \\
g(n)=\frac{e(n)+\gamma X^{T}(n) q(n-1)}{1+\alpha Y X^{T}(n) M_{1} X(n)} \\
q(n)=\frac{r}{\alpha+\gamma} q(n-1)-\alpha g(n) M_{1} X(n) \\
w(n)=w(n-1)+\alpha q(n)
\end{gathered}
$$

$$
\begin{gathered}
y(s)=x_{n}^{\prime} * w_{n} \\
e(n)=y(s)-\operatorname{sign}[y(s)] \\
g(n)=\frac{e(n)+\gamma X^{T}(n) q(n-1)}{1+\alpha \gamma X^{T}(n) m_{1} X(n)} \\
q(n)=\frac{\gamma}{\alpha+\gamma} q(n-1)-\alpha g(n) M_{1} X(n) \\
w(n)=w(n-1)+\alpha q(n)
\end{gathered}
$$

The blind channel equalization using the AR $\gamma$ in the direct decision configuration was implemented by setting up a value for Gamma between 0.01 and 1 and variating the two adjustment parameters - i.e., Alpha and M1 - in an interval between 0.01 and 6 with steps of 0.1 . With this, we gathered a minimal squared error of 0.022331 , with an Alpha value of 0.41 and $\mathrm{M} 1$ in 5.8. The results entail that for those Alpha, Gamma, and M1 values, a better estimation of the transmitted data and a considerable reduction of the squared error are obtained (see TABLE 2 and Figures 2 and 3$)$.

Table 2. Variation in Ar $\gamma$ parameters with decision statistics / Variación de los parámetros de Ar $\gamma$ con estadísticas de decisión

\begin{tabular}{rrrr}
\hline GAMA & MSE DD & Valor Alfa & Valor M1 \\
\hline 0.01 & 0.02818 & 0.31 & 0.4 \\
$\mathbf{0 . 0 3}$ & $\mathbf{0 . 0 2 2 3 3 1}$ & $\mathbf{0 . 4 1}$ & $\mathbf{5 . 8}$ \\
0.05 & 0.049 & 5.41 & 0.2 \\
0.07 & 0.045824 & 0.51 & 1 \\
0.09 & 0.027759 & 1.11 & 0.2 \\
0.1 & 0.03870 & 5.31 & 0.1 \\
0.3 & 0.039473 & 1.41 & 0.9 \\
0.5 & 0.04421 & 2.31 & 0.5 \\
0.7 & 0.04465 & 0.01 & 6 \\
1.0 & 0.0417 & 0.11 & 3.5 \\
\hline
\end{tabular}

\section{B. Estimator of the Sato Algorithm Adapted to the ARy One}

Equations (13) to (18) represent the $\mathrm{AR} \gamma$ algorithm with Sato statistics.

$$
\begin{gathered}
y(s)=x_{n}^{\prime} * w_{n} \\
e(n)=y(s)-(k * \operatorname{sign}[y(s)]) \\
k=\frac{E\left[x^{2}(n)\right]}{E[|x(n)|]} \\
g(n)=\frac{e(n)+r X^{T}(n) q(n-1)}{1+\alpha \gamma X^{T}(n) M_{1} X(n)} \\
q(n)=\frac{r}{\alpha+\gamma} q(n-1)-\alpha g(n) M_{1} X(n) \\
w(n)=w(n-1)+\alpha q(n)
\end{gathered}
$$

The second experiment was performed using the AR $\gamma$ with statistics of the Sato algorithm by variating the Alpha, Gamma, and M1 setup parameters. We observed 
that for a Gamma value of 0.03, Alpha in 0.16, and M1 in 5.9, we obtained a minimal squared error of 0.0020 . This result shows that with the use of the Sato statistics -which include the order 2 moments of the transmitted signal for the calculation of the error signal defining the new equalizer coefficients-, the data estimation is more optimum with a minimum squared error (see TABLE 3 and Figures 4 and 5).

Table 3. Variation in Ary parameters with decision statistics / Variación de los parámetros de Ary con estadísticas de decisión

\begin{tabular}{rrrr}
\hline GAMA & MSE Sato & Valor Alfa & Valor M1 \\
\hline 0.01 & 0.0024 & 0.11 & 5.3 \\
$\mathbf{0 . 0 3}$ & $\mathbf{0 . 0 0 2 0}$ & $\mathbf{0 . 1 6}$ & $\mathbf{5 . 9}$ \\
0.05 & 0.0027 & 0.31 & 0.6 \\
0.07 & 0.0326 & 5.71 & 6 \\
0.09 & 0.0599 & 0.11 & 3.7 \\
0.1 & 0.0897 & 0.51 & 0.2 \\
0.3 & 0.0950 & 5.51 & 5.5 \\
0.5 & 0.0956 & 0.11 & 0.5 \\
0.7 & 0.09764 & 0.31 & 0.1 \\
1.0 & 0.09876 & 0.01 & 0.7 \\
\hline
\end{tabular}

\section{Estimator of the Constant Module Algorithm Adapted to the ARy One}

Equations (19) to (24) represent the AR $\gamma$ algorithm with statistics of the Constant Module Algorithm [CMA] one.

$$
\begin{gathered}
y(s)=x_{n}^{\prime} * w_{n} \\
e(n)=y(s)-\left(y(s) *\left(k-|y(s)|^{2}\right)\right. \\
k=\frac{E\left[x^{2}(n)\right]}{E[|x(n)|]} \\
g(n)=\frac{e(n)+\gamma X^{T}(n) q(n-1)}{1+\alpha \gamma X^{T}(n) M_{1} X(n)} \\
q(n)=\frac{r}{\alpha+\gamma} q(n-1)-\alpha g(n) M_{1} X(n) \\
w(n)=w(n-1)+\alpha q(n)
\end{gathered}
$$

The last experiment was performed by implementing a channel equalizer with the AR $\gamma$ algorithm using the statistics of the CMA, which include the moments of order 4 and 2 of the transmitted signal. The results show that with the following values: Gamma $=0.03$; Alpha $=5.71$, and M1 $=5.8$, a minimal squared error of 0.0014 is obtained. This last value represents a better performance relative to the Sato and decision algorithms. With these results, we obtained an equalization with values much closer to the transmitted ones with a minimum squared error (see TABLE 4 and Figures 6 and 7).
El segundo experimento se realizó utilizando el AR $\gamma$ con estadísticas del algoritmo de Sato, variando los parámetros de ajuste Alfa, Gama y M1. Se observa que para un valor de gama de 0.03 , alfa de 0.16 y M1 de 5.9 se obtiene un error cuadrático mínimo de 0.0020. Este resultado muestra que con el uso de las estadísticas de Sato -las cuales incluyen los momentos de orden dos de la señal transmitida, para el cálculo de la señal de error que define los nuevos coeficientes del ecualizador-, la estimativa de los datos es mucho más óptima, con un error cuadrático mínimo (ver Tabla 3 y Figuras 4 y 5 ).

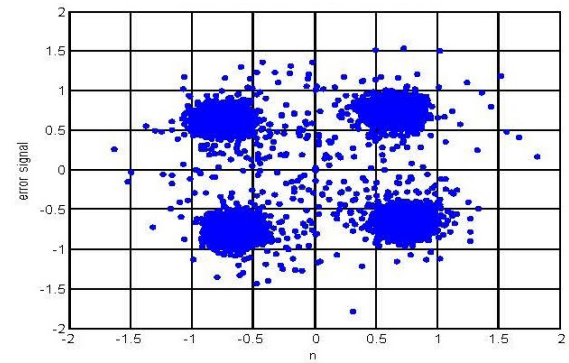

Figure 4. Equalization with Sato statistics / Ecualización con estadísticas de Sato

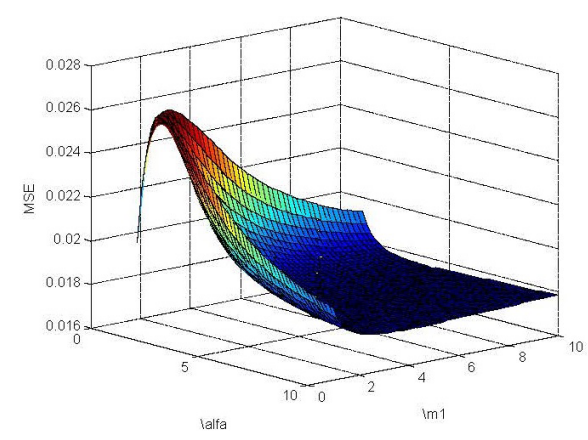

Figure 5. MSE with variations in alpha and M1 / MSE con la variación de alfa y $\mathrm{M} 1$

C. Estimador del algoritmo de módulo constante adaptado al algoritmo $A R \gamma$

Las ecuaciones (19) a (24) representan al algoritmo AR $\gamma$ con estadísticas de CMA.

$y(s)=x_{n}^{\prime} * w_{n}$
$e(n)=y(s)-\left(y(s) *\left(k-|y(s)|^{2}\right)\right.$
$k=\frac{E\left[x^{2}(n)\right]}{E[|x(n)|]}$
$g(n)=\frac{e(n)+\gamma X^{T}(n) q(n-1)}{1+\alpha \gamma X^{T}(n) M_{1} X(n)}$
$q(n)=\frac{r}{\alpha+\gamma} q(n-1)-\alpha g(n) M_{1} X(n)$
$w(n)=w(n-1)+\alpha q(n)$


El último experimento se realizó implementando un ecualizador de canal con el algoritmo AR $\gamma$ utilizando las estadísticas del algoritmo CMA, las cuales incluyen los momentos de orden cuatro y de orden dos de la señal transmitida. Los resultados muestran que con valores de gama de 0.03 , Alfa de 5.71 y M1 de 5.8 se obtiene un mínimo error cuadrático de 0.0014 , lo que corresponde a un mejor desempeño frente a las estadísticas de los algoritmos de Sato y de decisión. Con estos resultados se obtiene un ecualización mucho más próxima a los valores transmitidos con un error cuadrático mínimo (ver Tabla 4 y Figuras 6 y 7$)$.

Table 4. Variation in Ary parameters with CMA statistics / Variación de los parámetros de Ar $\gamma$ con estadísticas de CMA

\begin{tabular}{rrrr}
\hline GAMA Variable & MSE CMA & Valor Alfa & Valor M1 \\
\hline 0.01 & 0.0085 & 0.41 & 0.5 \\
$\mathbf{0 . 0 3}$ & $\mathbf{0 . 0 0 1 4}$ & $\mathbf{5 . 7 1}$ & $\mathbf{5 . 8}$ \\
0.05 & 0.0254 & 0.81 & 1.4 \\
0.07 & 0.0659 & 5.41 & 0.2 \\
0.09 & 0.0805 & 0.61 & 1 \\
0.1 & 0.0865 & 3.31 & 0.2 \\
0.3 & 0.0902 & 3.31 & 0.1 \\
0.5 & 0.0943 & 1.31 & 0.1 \\
0.7 & 0.104 & 0.01 & 1.9 \\
1.0 & 0.158 & 0.11 & 0.1 \\
\hline
\end{tabular}

\section{Conclusiones}

La ecualización ciega de canal ha sido empleada como una técnica de estimación de canal para resolver problemas de detección de la señal transmitida en canales telefónicos e inalámbricos, en los que es poco práctico usar secuencias de entrenamiento para realizar una correcta estimación de los datos, de ahí que se conoce como un método de estimación de la señal de salida que trabaja con estadísticas de orden superior de la señal de entrada, en ausencia de secuencias de entrenamiento, lo cual optimiza el uso de la capacidad del canal.

Los resultados de la implementación del ecualizador ciego utilizando el algoritmo AR $\gamma$ y las estadísticas de orden superior de los algoritmos de Bussgang, muestran la ecualización ciega de canal a partir de un error cuadrático mínimo y con mayor estimativa de los datos transmitidos, teniendo en cuenta que la variación de los parámetros de ajuste del algoritmo proporciona valores mínimos del error cuadrático medio, es necesario tener en cuenta que, para valores de gama mayores a 1, el algoritmo se vuelve inestable y el proceso de detección presenta ambigüedades.

Un análisis en los diferentes escenarios propuestos refleja que el algoritmo adaptativo simulado depende de los parámetros de ajuste y de la utilización de estadísticas de segundo orden y de orden superior, para realizar una estimación cercana a los datos transmitidos.

Finalmente, de los resultados obtenidos en las simulaciones se logra concluir que las estadísticas del algoritmo de modu-

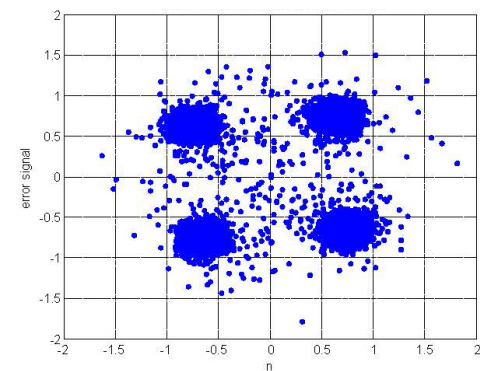

Figure 6. Equalization with CMA statistics / Ecualización con estadísticas de CMA

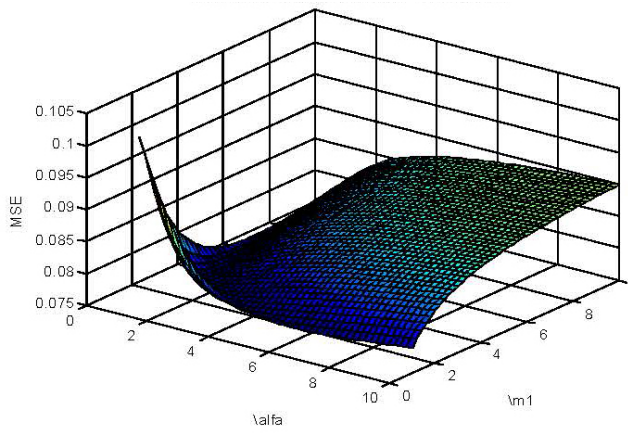

Figure 7. MSE with variations in alpha and M1 / MSE con la variación de alfa y M1

\section{Conclusions}

The blind channel equalization has been employed as a channel estimation technique to solve problems related with detection of the transmitted signal in telephonic and wireless channels, where it is not practical to employ training sequences to perform a correct estimation of the data. Therefore, this method is known as an estimation method of the output signal working with superior order statistics of the input signal and in absence of training sequences, which optimizes the channel capacity.

The results of the blind equalizer implementation by using the $\mathrm{AR} \gamma$ algorithm and the superior order statistics of the Bussgang algorithms show the blind channel equalization through a minimal squared error and with larger estimation of the transmitted data. This, by considering that the variation of the algorithm setup parameters provides minimal values of the mean squared error. It is important to consider that for Gamma values larger than 1, the algorithm becomes unstable and the detection process presents ambiguities.

The analysis in the different proposed scenarios reflect that the simulated adaptive algorithm depends on the setup parameters and the use of the second and superior order statistics to perform a close estimation of the transmitted data.

Finally, from the obtained results in the simulations, we can conclude that the statistics of the constant module algo- 
rithm present better convergence speeds in the calculation of the mean squared error: we obtained an MSE of 0.0014 with Alpha $=5.71$ and $\mathrm{Ml}=5.8$. Consequently, a better detection of the transmitted symbols is obtained compared to the Sato and decision algorithms, which allows a better reliability in the detection of the transmitted symbols.s. lo constante presentan mejor velocidad de convergencia en el cálculo del error cuadrático medio: se obtiene un MSE de 0.0014 con alfa de 5.71 y un ml de 5.8 y, por ende, una mejor detección de los símbolos transmitidos en comparación con los algoritmos de Sato y de decisión, lo cual permite una mayor confiabilidad en la detección de los símbolos transmitidos.SST 


\section{References / Referencias}

Aquino, F. (2012). Uso de un procesamiento largamente en un equalizador fraccionalmente espaciado aplicado a canales de comunicación selectivos en frecuencia. Holos, 4, 113-125.

Benveniste, A., Goursat, M., \& Ruget, G. (1980). Robust identification of a nonminimum phase system: Blind adjustment of a linear equalizer in data communications. IEEE Transactions on Automatic Control, 25(3), 385-399.

Erdogmus, D., \& Principe, J. C. (2002). An error-entropy minimization algorithm for supervised training of nonlinear adaptive systems. IEEE Transactions on Signal Processing, 50(7), 1780-1786.

Jojoa, P. (2003). Um algoritmo acelerador de parametros [Ph.D. thesis]. Escola Politécnica de São Paulo: Brasil.

Lathi, B. (1998). Modern digital and analog communication system [3rd ed.). New York, NY: Oxford University.

Lucky, R. W. (1966). Techniques for adaptive equalization of digital communication systems. Bell Labs Technical Journal, 45(2), 255-286.

Lugannani, R. (1969). Intersymbol interference and probability of error in digital systems. IEEE Transactions on Information Theory, 15(6), 682-688.

Madeira., T. (2005). Un estudio sobre técnicas de ecualización autodidacta [Ph.D. thesis]. Escola Politécnica de São Paulo: Brasil..

Madeira., T. (2013). Ecualización autodidacta basada en combinación de filtros adaptativos. [MSc. thesis]. Escola Politécnica de São Paulo: Brasil.

Neves, A., Attux, R., Suyama, R., Miranda, M., Romano, J. (2006). Sobre criterios para ecualización no supervisada. Revista Controle \& Automação, 17(3), 278-299.

Rocha, P. (2005). Desarrollo de algoritmos de procesamiento digital de señales para la reconstrucción de imágenes usando biespectro. [MSc. thesis]. Centro Nacional de Investigación y Desarrollo Tecnológico: Cuernavaca, México.

Rolim, C. (2005). Ecualización adaptativa y autodidacta de canalaes lineales y no lineales utilizando el algoritmo de módulo constante [MSc. thesis]. Universidad en la Arquidiócesis de Fortaleza: Brasil.

Romano, J. M. T., Attux, R., Cavalcante, C. C., \& Suyama, R. (2016). Unsupervised signal processing: channel equalization and source separation. Boca Raton, FL: CRC.

Saltzberg, B. (1968). Intersymbol interference error bounds with application to ideal bandlimited signaling. IEEE Transactions on Information Theory, 14(4), 563-568.

Sato, Y. (1975). A method of self-recovering equalization for multilevel amplitude-modulation systems. IEEE Transactions on communications, 23(6), 679-682.

Shalvi, O., \& Weinstein, E. (1990). New criteria for blind deconvolution of nonminimum phase systems (channels). IEEE Transactions on Information Theory, 36(2), 312-321.

Solarte, V. (Noviembre de 2012). El algoritmo acelerador regresivo versión $\gamma$ (AR $\gamma$ ) y los efectos de cuantificación. Revista Universitaria en Telecomunicaciones Informática y Control., 1(2), 9.

Widrow, B. \& Hoff, M. (1960). Adaptative switching circuits. In 1960 IRE WESCON Convention Record, Part 4, (pp 96-104). New York, NY: Institute of Radio Engineers. 
Hurtado, J., \& Jojoa, P. (2018).

\section{CURRICULUM VITAE}

Johanna Andrea Hurtado Sánchez Engineer in Computer Science from the Benemérita Universidad Autónoma de Puebla (Mexico). Development of elements for Internet of Things [loT] is his main area of interest in research / Licenciado en Ingeniería en Ciencias de la Computación en la Benemérita Universidad Autónoma de Puebla (México), su principal área de interés en investigación es el desarrollo de elementos de Internet de las Cosas [loT].

Pablo Emilio Jojoa Gómez Electronics and Telecommunications Engineer from the Universidad del Cauca (Popayán, Colombia), with Master in Science (M.Sc.) and Doctorate (Ph.D.) in Electrics Engineering with emphasis in Electronic Systems from the Universidad de São Paulo. He is an associated professor of the Telecommunications Department in the Electronics and Telecommunications Engineering Faculty. He is also the coordinator of the research group in new telecommunication technologies [GNTT, Grupo de Nuevas Tecnologías en Telecomunicaciones]. His largest research interest area is the digital signal processing / Ingeniero en Electrónica y Telecomunicaciones de la Universidad del Cauca (Popayán, Colombia), con Maestría y Doctorado en Ingeniería Eléctrica con énfasis en Sistemas Electrónicos de la Universidad de São Paulo (Brasil). Es profesor titular del Departamento de Telecomunicaciones de la Facultad de Ingeniería Electrónica y Telecomunicaciones de la Universidad del Cauca y Coordinador del grupo de Investigación y Desarrollo en Nuevas Tecnologías en Telecomunicaciones [GNTT]. Su mayor área de interés profesional es el procesamiento digital de señales. 